\title{
KEMAMPUAN PENALARAN MATEMATIS: ANALISIS BERDASARKAN GAYA KOGNITIF SISWA
}

\author{
Ela Priastuti Mirlanda ${ }^{1}$, Heni Pujiastuti ${ }^{2}$ \\ ${ }^{1}$ Universitas Sultan Ageng Tirtayasa \\ ela.priastuti@yahoo.co.id \\ ${ }^{2}$ Universitas Sultan Ageng Tirtayasa \\ henipujiastuti@untirta.ac.id
}

\begin{abstract}
ABSTRAK
Penelitian ini bertujuan untuk menganalisis kemampuan penalaran matematis siswa SMA yang ditinjau dari gaya kognitif Field Independent dan Field Dependent. Populasi dalam penelitian ini adalah siswa kelas X SMA Negeri 1 Rangkasbitung dengan sampel sebanyak dua kelas. Instrumen penelitian berupa tes GEFT untuk mengukur gaya kognitif dan tes tulis berbentuk essay untuk mengukur kemampuan penalaran matematika. Penelitian ini menunjukkan bahwa dari $45 \%$ siswa yang memiliki gaya kognitif field dependent (FD) memiliki nilai rata-rata tes kemampuan penalaran matematis sebesar 58,95 sementara 55\% siswa yang memiliki gaya kognitif field independent (FI) memiliki nilai rata-rata tes kemampuan penalaran matematis sebesar 61,87 . Hasil uji statistik menunjukkan gaya kognitif Field Dependent berpengaruh terhadap kemampuan penalaran matematis sebesar 14,6\% dan gaya kognitif Field Independent berpengaruh terhadap kemampuan penalaran matematis sebesar $31,3 \%$. Dari tiga indikator kemampuan penalaran matematis yang diteliti, kemampuan menggunakan pola, menganalisis situasi matematis dan memberi penjelasan menggunakan model dalam penyelesaian masalah matematika merupakan hal yang masih sulit dikuasai oleh siswa. Sementara kemampuan melaksanakan perhitungan berdasarkan aturan atau rumus tertentu telah dikuasai oleh siswa dengan nilai rata-rata baik. Dengan mengetahui perbedaan jenis gaya kognitif siswa dan karakteristiknya, kegiatan pembelajaran matematika harus dirancang sedemikian rupa agar dapat menumbuhkan dan mengembangkan kemampuan penalaran matematis siswa.
\end{abstract}

Kata Kunci: kemampuan penalaran matematis, gaya kognitif siswa, field independent, field dependent.

\begin{abstract}
This study aims to analyze the mathematical reasoning abilities of high school students in terms of the cognitive style of the Field Independent and Field Dependent. The population in this study were grade $X$ students of SMA Negeri 1 Rangkasbitung with a sample of two classes. The research instrument was a GEFT test to measure cognitive style and essay tests to measure mathematical reasoning abilities. This study shows that $45 \%$ of students who have a field dependent (FD) cognitive style have an average value of mathematical reasoning ability test of 58.95 while $55 \%$ of students who have an field independent cognitive style (FI) have an average ability test score mathematical reasoning of 61.87 . The results of statistical tests showed that the cognitive style of the Field Dependent had an effect on mathematical reasoning abilities of $14.6 \%$ and the cognitive style of the Field Independent had an effect on mathematical reasoning abilities of $31.3 \%$. Of the three indicators of mathematical reasoning ability studied, the ability to use patterns, analyze mathematical situations and give explanations to use models in solving mathematical problems are things that are still difficult for students. While the ability to carry out calculations based on certain rules or formulas has been mastered by students with good average grades. By knowing the different types of cognitive styles of students and their characteristics,
\end{abstract}


mathematics learning activities must be designed in such a way as to grow and develop students' mathematical reasoning abilities.

Keywords: mathematical reasoning, cognitive style, field independent, field dependent.

\section{PENDAHULUAN}

Matematika merupakan salah satu pelajaran yang mampu mengembangkan kemampuan penalaran siswa karena matematika memiliki struktur dan keterkaitan yang kuat dan jelas antara konsep-konsep-konsep. Penalaran dalam matematika merupakan sesuatu yang pokok dan penting, tidak pernah sedikitpun penalaran lepas dari matematika, sehingga dapat dikatakan bahwa penalaran adalah intinya matematika (Fisher, 2017).

Kemampuan penalaran matematis merupakan kompetensi yang terbentuk dari interaksi siswa dengan matematika sejalan dengan tahapan berpikir yang dikemukakan oleh Piaget. Tahapan berpikir Piaget yang terakhir adalah tahap operasi formal yang memungkinkan seorang siswa memiliki kemampuan intelektual untuk melakukan penalaran formal yang menjadi dasar bagi banyak pencapaian di dunia (Hill, 2010). Seperti yang diuraikan dalam Standar Isi Pendidikan Dasar dan Menengah (Kemendikbud, 2016) bahwa siswa sekolah menengah tingkat X-XII harus memiliki kompetensi dalam menjelaskan pola dan menggunakannya untuk melakukan prediksi dan kecenderungan jangka panjang; menggunakannya untuk memprediksi kecenderungan (trend) atau memeriksa kesahihan argumen, yang merupakan indikator dari kemampuan penalaran matematika.

The National Council of Teachers of Mathematics menyatakan bahwa, Mathematical reasoning and proof offer powerful ways of developing and expressing insights about a wide range of phenomena. People who reason and think analytically tend to note patterns, structure, or regularities in both real-world and mathematical situations. They ask if those patterns are accidental or if they occur for a reason. They make and investigate mathematical conjectures. They develop and evaluate mathematical arguments and proofs, which are formal ways of expressing particular kinds of reasoning and justification (Ferrini-Mundy, 2001). Dalam arti yang sederhana NCTM menyebutkan bahwa kemampuan penalaran matematis meliputi: (1) menyelesaikan masalah dalam menemukan pola, struktur dan kesamaan aturan dalam kehidupan sehari-hari dalam model matematika; (2) membuat generalisasi dari konjektur-konjektur ; (3) mengembangkan dan mengevaluasi argumen dan bukti matematis, sebagai cara formal untuk mengekspresikan 
jenis penalaran dan pembenaran. Dengan kemampuan penalaran matematika, siswa dapat menyusun dugaan berdasarkan atas pemahaman dan pengalamannya akan konsep matematika yang telah ia pelajari sehingga mampu mengaitkannya dan menemukan solusi dari masalah yang ia hadapi.

Indikator penalaran matematis yang lain dikemukakan oleh Sumarmo (2007) yaitu menarik kesimpulan logis, memberi penjelasan dengan menggunakan model, menggunakan pola dan hubungan untuk menganalisis situasi matematik, melaksanakan perhitungan berdasarkan aturan atau rumus tertentu, menyusun dan menguji konjektur, memberikan contoh penyangkal, mengikuti aturan inferensi, memeriksa validitas argumen, menyusun argumen yang valid, menyusun pembuktian langsung dan pembuktian tak langsung serta menggunakan induksi matematika. Berdasarkan pada penjelasan diatas, untuk penelitian ini penulis akan menganalisis kemampuan penalaran matematis dengan indikator yaitu 1) memberi penjelasan dengan menggunakan model, 2) menggunakan pola dan hubungan untuk menganalisis situasi matematik dan 3) melaksanakan perhitungan berdasarkan aturan atau rumus tertentu.

Bernalar secara matematis merupakan kebiasaan pikiran dan seperti semua kebiasaan lainnya, inipun dibangun lewat penggunaan yang terus menerus di dalam berbagai konteks (Nufus \& Ariawan, 2017). Kemampuan penalaran matematis dipengaruhi oleh faktor intrinsik siswa, yaitu gaya kognitif yang dikembangkan oleh Witkin, Moore, Goodenough dan Cox (1977). Seperti juga dalam penelitian Basir (2015) yang menyatakan bahwa gaya kognitif siswa yang berbeda-beda dapat mempengaruhi kemampuan siswa dalam berpikir dan bernalar dalam menyelesaikan soal. Gaya kognitif Field Dependent dan Field Independent berkaitan erat dengan variabel lain seperti jenis kelamin, pilihan karir dan prestasi akademik siswa (Onyekuru, 2015). Rozestraten dan Pottier (1988) menemukan hubungan antara level akademik dengan gaya kognitif Field Dependent dan Field Independent. Sementara Ngilawajan (2013) menjelaskan bahwa setiap orang memiliki cara-cara khusus dalam bertindak, yang dinyatakan melalui aktivitas-aktivitas perseptual dan intelektual secara konsisten. Aspek perseptual dan intelektual mengungkapkan bahwa setiap individu memiliki ciri khas yang berbeda dengan individu lain. Sesuai dengan tinjauan aspek tersebut, perbedaan individu dapat diungkapkan oleh tipe-tipe kognitif yang dikenal dengan istilah gaya kognitif. Gaya kognitif adalah karakteristik atau cara khas siswa dalam memperoleh, menyusun dan menggunakan informasi untuk menghadapi dan menyelesaikan permasalahan. Gaya kognitif, menurut Hidayat (2013) dapat dibedakan berdasarkan perbedaan psikologis yaitu : gaya kognitif 
Field Dependent (FD) dan Field Independent (FI). Orang FD melihat isyarat lingkungan sebagai petunjuk dalam merespon suatu stimulus dan memandang informasi secara umum. Orang yang memiliki gaya kognitif Field Dependent (FD) dikategorikan sebagai seorang yang dapat berpikir secara global, berperilaku sensitif secara sosial dan berorientasi interpersonal, lebih suka bekerja kelompok dalam mengerjakan tugasnya. Hal ini menyebabkan siswa FD cenderung memerlukan bantuan dan penguatan dari luar untuk mencapai tujuan. Sebaliknya seorang yang memiliki gaya kognitif Field Independent (FI) cenderung kurang tertarik dengan fenomena sosial dan lebih suka dengan ide-ide dan prinsip-prinsip yang abstrak, kurang hangat dalam hubungan interpersonal, dalam mengerjakan tugasnya merasa efisien bekerja sendiri. Karenanya siswa FI mampu memotivasi diri sendiri dalam mencapai tujuan. Orang FI merespon suatu tugas cenderung mengacu pada syarat-syarat dari dalam diri sendiri dan mampu menganalisanya ke dalam bagian-bagian yang lebih rinci (Khoiriyah, 2013).

Dalam penelitian ini, peneliti fokus untuk menganalisis kemampuan penalaran matematis pada tipe gaya kognitif Field Dependent dan Field Independent. Perbedaan mendasar dari kedua gaya kognitif tersebut yaitu dalam hal bagaimana melihat suatu permasalahan. Karakteristik dasar dari kedua gaya kognitif tersebut sesuai untuk diterapkan dalam penelitian yang melibatkan kemampuan penalaran matematis. Selain itu, karakteristik kedua gaya kognitif tersebut sesuai dengan kondisi banyak siswa yang ditemui penulis di lapangan sehingga hal ini yang menjadi alasan bagi penulis untuk memilih gaya kognitif Field Independent-Field Dependent yang dikaitkan dengan kemampuan penalaran matematis untuk menjadi fokus penelitian.

Materi sistem persamaan linier tiga variabel (SPLTV) merupakan perluasan materi persamaan linier dan sistem persamaan linier dua variabel yang telah diberikan di tingkat sekolah menengah pertama. Kajian materi SPLTV di sekolah menengah atas lebih banyak dikaitkan dengan permasalahan dalam kehidupan nyata yang menyatu dengan fakta dan lingkungan sekitar. Oleh karena itu dalam menyelesaikan masalah SPLTV siswa dituntut untuk memiliki pola pikir dan cara belajar yang mendorong ditemukannya ide - ide, proses bernalar dan kreatifitas dalam menyusun strategi penyelesaian masalah. Proses bernalar ditempuh siswa mulai dengan menterjemahkan masalah menjadi sebuah model matematika sampai dengan menemukan solusi dan menafsirkannya. Sementara itu gaya kognitif siswa mempengaruhi bagaimana siswa melihat permasalahan SPLTV dan menentukan strategi penyelesaian yang tepat. 
Penelitian ini bertujuan untuk menganalisis kemampuan penalaran matematis siswa berdasarkan pada gaya kognitif Field Dependent (FD) dan Field Independent (FI) dalam menyelesaikan masalah matematika materi Sistem Persamaan Linier Tiga Variabel (SPLTV). Dengan demikian permasalahan yang dirumuskan adalah bagaimana kemampuan penalaran matematis pada materi Sistem Persamaan Linier Tiga Variabel (SPLTV) ditinjau dari gaya kognitif siswa Field Dependent dan Field Independent?

\section{METODE PENELITIAN}

Penelitian dilakukan pada siswa kelas X IPS SMA Negeri 1 Rangkasbitung. Dipilihnya subjek siswa kelas X karena mereka berusia antara 15 - 16 tahun berada pada tahap perkembangan operasi formal menurut Piaget (Ibda, 2015). Pada periode ini ia tidak perlu berpikir dengan pertolongan benda atau peristiwa konkrit, ia mempunyai kemampuan untuk berpikir abstrak. Selain itu, siswa kelas $\mathrm{X}$ dianggap telah cukup memiliki pengetahuan yang diperlukan dalam menyelesaikan tugas yang berkaitan dengan kemampuan penalaran matematis seperti yang telah disebutkan di atas yaitu :1) memberi penjelasan dengan menggunakan model, 2) menggunakan pola dan hubungan untuk menganalisis situasi matematik dan 3) melaksanakan perhitungan berdasarkan aturan atau rumus tertentu.

Prosedur pelaksanaan penelitian dimulai dengan memberikan tes GEFT (Group Embedded Figure Test) kepada siswa untuk membedakan jenis gaya kognitif siswa. Setelah diperoleh hasilnya, kemudian siswa diberikan tes tulis untuk mengukur kemampuan penalaran matematis berupa soal berbentuk uraian agar terlihat tahapan penyelesaian masalah yang dikerjakan oleh siswa. Instrumen tes yang digunakan pada penelitian ini adalah tes kemampuan penalaran dan tes GEFT untuk menentukan jenis gaya kognitif siswa.

\section{Tes Kemampuan Penalaran matematis}

Tes kemampuan penalaran matematis dibuat untuk mengukur sejauh mana kemampuan penalaran matematis yang telah dimiliki siswa. Tes yang diberikan adalah 3 buah soal berbentuk uraian. Hal ini dilakukan karena bentuk tes uraian akan memberikan kebebasan kepada siswa untuk mengekspresikan daya nalarnya, sehingga jawaban yang diberikan oleh setiap penempuh tes akan menunjukkan kemampuan berpikir secara kompleks (Susongko, 2010). Dengan demikian siswa akan mengorganisasikan dan menuliskan jawaban dengan kalimatnya sendiri sehingga kemampuan penalaran matematis 
siswa terlihat dengan jelas. Indikator tes kemampuan penalaran matematis yang akan digunakan dalam penelitian ini yaitu, 1) Memberi penjelasan dengan menggunakan model; 2) Menggunakan pola dan hubungan untuk menganalisis situasi matematik; dan 3) Melaksanakan perhitungan berdasarkan aturan atau rumus tertentu.

Tes disusun dan dikembangkan oleh peneliti berdasarkan prosedur penyusunan instrumen tes yang baik dan benar menurut panduan penilaian dari PSMA Kemdikbud (Pendidikan Sekolah Menengah Atas). Kaidah penulisan soal bentuk uraian sebagai berikut: (a) Soal sesuai dengan indikator, (b) Batasan pertanyaan dan jawaban yang diharapkan sesuai, (c) Ada petunjuk yang jelas mengenai cara mengerjakan soal, (d) Rumusan kalimat soal/pertanyaan menggunakan kata tanya atau perintah yang menuntut jawaban terurai dan (e) Ada pedoman penskoran. Kriteria hasil tes kemampuan penalaran matematis dibedakan berdasarkan kriteria nilai UN yang ada pada Tabel 1.

\begin{tabular}{ccc}
\multicolumn{3}{c}{ Tabel 1. Kriteria hasil tes kemampuan penalaran } \\
\hline No & Kriteria & Nilai $(\mathrm{N})$ \\
\hline 1 & Sangat baik & $85<\mathrm{N} \leq 100$ \\
2 & Baik & $70<\mathrm{N} \leq 85$ \\
3 & Cukup & $55<\mathrm{N} \leq 70$ \\
4 & Kurang & $0 \leq \mathrm{N} \leq 55$ \\
\hline
\end{tabular}

\section{Tes Group Embed Figure Test (GEFT)}

Penentuan gaya kognitif Field Dependent (FD) dan Field Independent (FI) dilakukan dengan memberikan test GEFT (Group Embed Figure Test) (Basir, 2015). GEFT terdiri dari 25 item berupa gambar kompleks yang dibagi menjadi tiga bagian pengerjaan selama 15 menit. Bagian pertama berisi tujuh item untuk latihan, bagian kedua dan ketiga masing-masing berisi sembilan item untuk tes dan penskoran. Skor total diperoleh dari sejumlah gambar yang berhasil atau benar dalam pencarian gambar kompleks pada bagian kedua dan ketiga pengerjaan tes.

Tabel 2. Pedoman Penskoran Gaya Kognitif

\begin{tabular}{ccc}
\hline Category & Female Score & Male Score \\
\hline FD & $0-11$ & $0-12$ \\
FI & $12-18$ & $13-18$ \\
\hline
\end{tabular}

\section{HASIL DAN PEMBAHASAN}

Hasil tes GEFT yang diperoleh merupakan gambaran gaya kognitif siswa yang ada pada Gambar 1. 


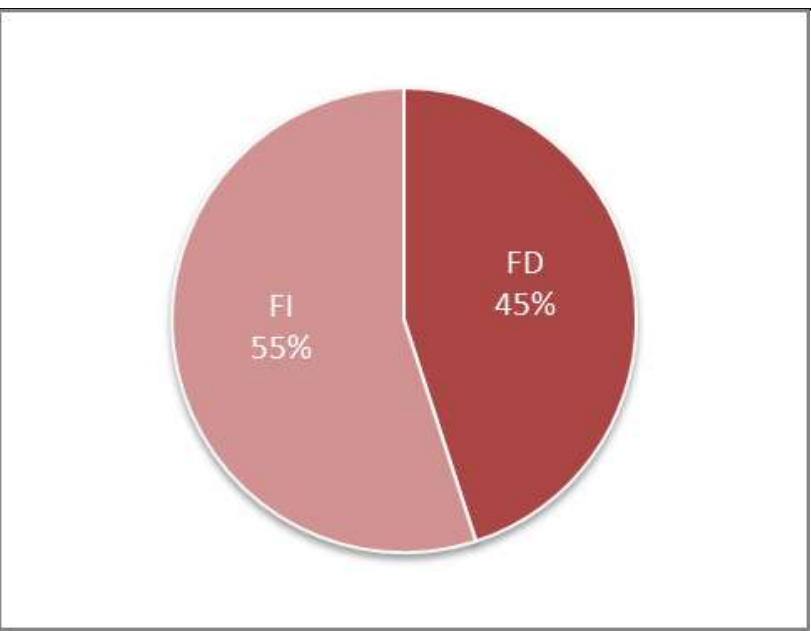

Gambar 1. Sebaran Gaya Kognitif Siswa

Setelah diperoleh sebaran gaya kognitif siswa dalam 2 kelompok tersebut, seluruh siswa kemudian diberikan soal tes penalaran matematis berupa 3 buah soal uraian. Hasil yang diperoleh ada pada Gambar 2.

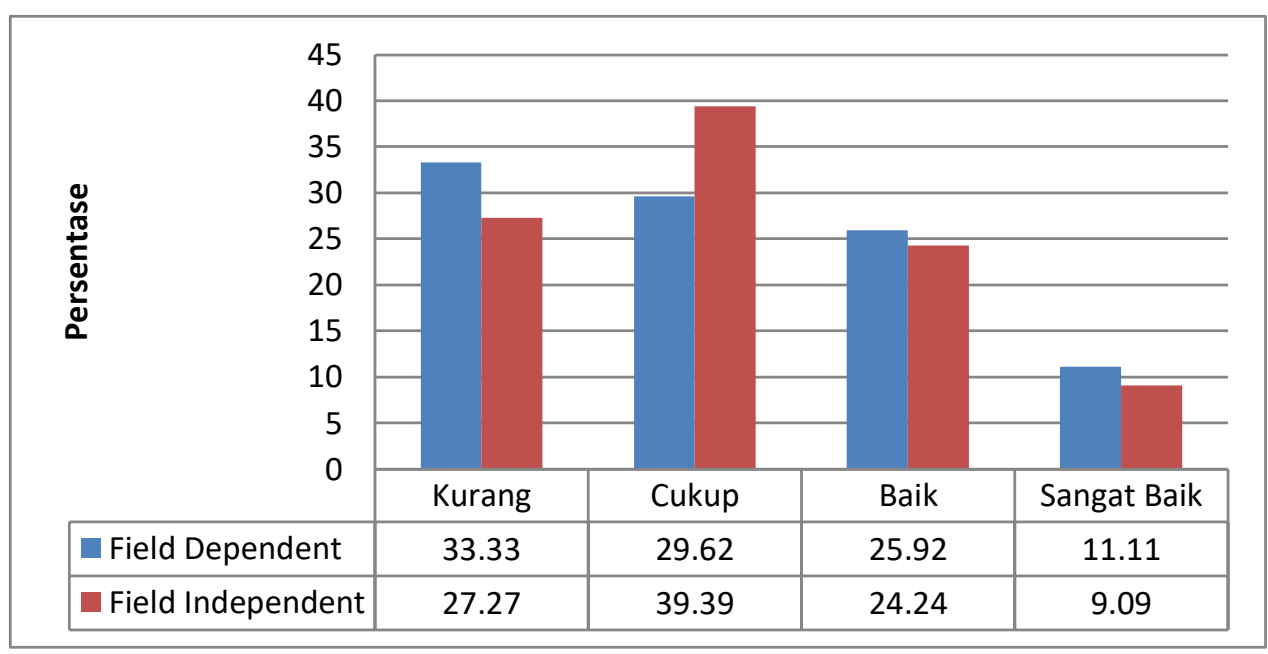

Gambar 2. Sebaran Nilai Tes Kemampuan Penalaran Matematis Berdasarkan Kriteria Nilai UN

Dari hasil penilaian tes kemampuan penalaran matematis diatas menunjukkan 33,33\% siswa yang memiliki gaya kognitif field dependent (FD) memiliki nilai kurang dan $66,67 \%$ siswa lainnya memiliki nilai cukup sampai sangat baik. Sedangkan siswa yang memiliki gaya kognitif field independent (FI) sebanyak 27,27\% memiliki nilai kurang dan 72,73\% lainnya memiliki nilai cukup sampai sangat baik. Ini berarti secara umum siswa yang memiliki gaya kognitif field independent (FI) memiliki kemampuan penalaran matematis lebih baik daripada siswa yang memiliki gaya kognitif field dependent (FD).

Hasil penelitian menunjukkan bahwa dari $45 \%$ siswa yang memiliki gaya kognitif field dependent (FD) memiliki nilai rata-rata tes kemampuan penalaran matematis sebesar 58,95 sementara 55\% siswa yang memiliki gaya kognitif field independent (FI) memiliki 
nilai rata-rata tes kemampuan penalaran matematis sebesar 61,87 dengan sebaran nilai ratarata untuk tiap indikator soal terlihat pada Gambar 3.

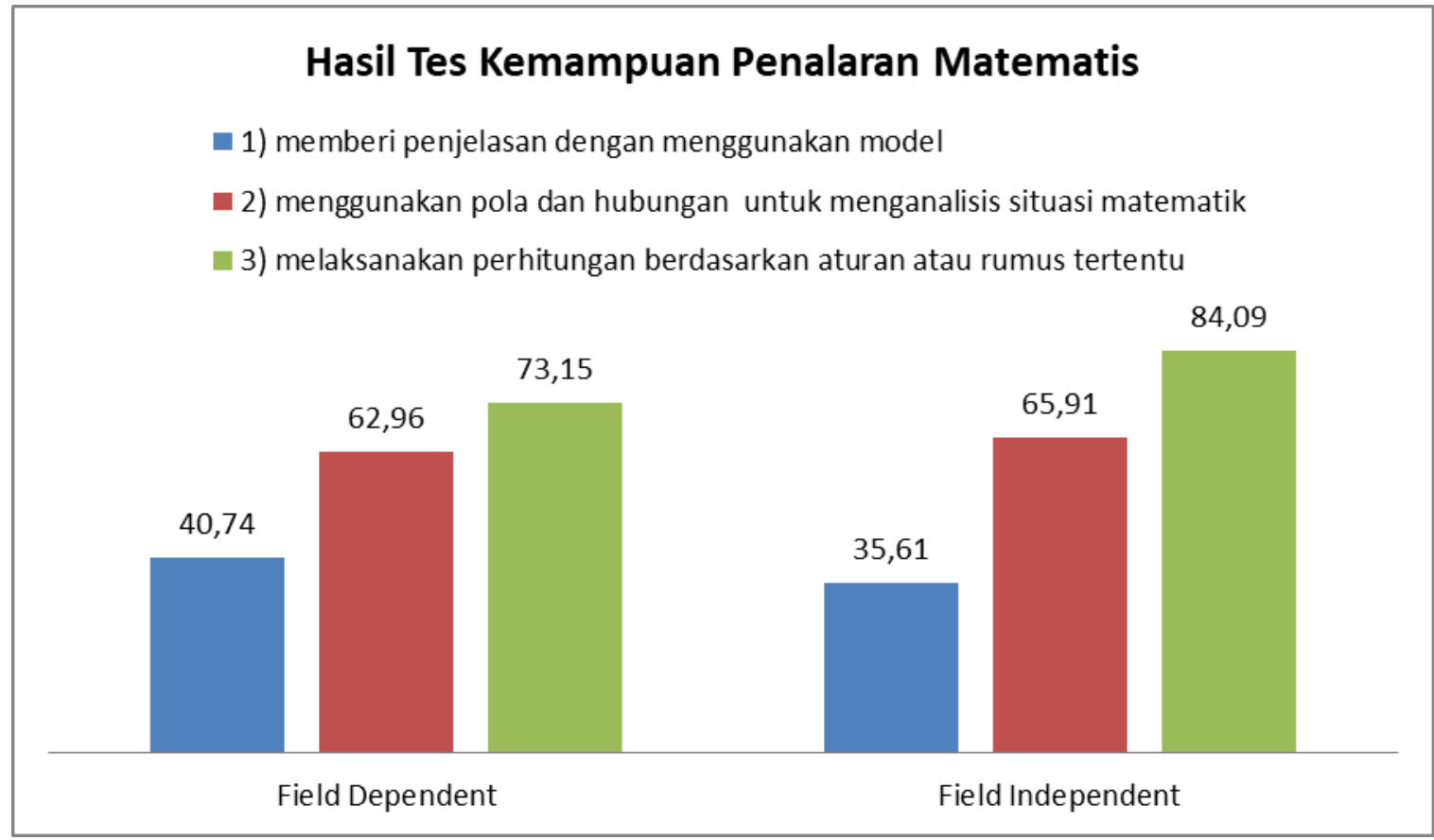

Gambar 3. Rata-rata hasil tes penalaran matematis berdasarkan gaya kognitif

Pada Gambar 3 terlihat kedua kelompok siswa memiliki nilai kurang pada kemampuan memberi penjelasan dengan menggunakan model, nilai cukup pada kemampuan menggunakan pola dan hubungan untuk menganalisis situasi matematik dan nilai baik pada kemampuan melaksanakan perhitungan berdasarkan aturan atau rumus tertentu. Nilai rata-rata untuk indikator 1 yaitu memberi penjelasan dengan menggunakan model menunjukkan siswa yang memiliki gaya kognitif field dependent (FD) lebih baik dari nilai rata-rata siswa yang memiliki gaya kognitif field independent (FI). Soal untuk indikator 1 bersifat rutin, hal ini menyebabkan siswa dengan FD dapat lebih baik menyelesaikannya dibandingkan dengan siswa FI yang cenderung menyukai soal yang menantang.

Penyelesaian soal SPLTV dengan metode eliminasi, substitusi atau determinan matriks rumit dan membutuhkan waktu yang cukup lama, kecuali jika siswa memiliki kemampuan dalam memanipulasi persamaan-persamaan linier tersebut dengan trik atau teknik yang dapat membuat soal tersebut lebih mudah diselesaikan. Hal ini terlihat pada soal dengan indikator 2 yaitu menggunakan pola dan hubungan untuk menganalisis situasi matematik, siswa FI yang memiliki kemampuan lebih baik dalam menganalisis suatu permasalahan memiliki nilai rata-rata lebih tinggi daripada siswa FD. Begitu pula untuk soal dengan indikator 3 yaitu melaksanakan perhitungan berdasarkan aturan atau rumus tertentu, siswa FI memiliki nilai rata-rata yang lebih tinggi dibandingkan dengan siswa FD 
karena siswa FI cenderung menyelesaikan soal tidak dengan cara yang rutin, mereka mampu membuat prosedur yang rumit menjadi lebih sederhana dan lebih mudah diselesaikan.

\section{Siswa yang Memiliki Gaya Kognitif Field Dependent (FD)}

Siswa yang memiliki gaya kognitif Field Dependent memiliki nilai rata - rata kurang untuk indikator 1 yaitu memberi penjelasan dengan menggunakan model. Dalam hal melaksanakan perhitungan berdasarkan aturan atau rumus tertentu siswa FD lebih baik dibandingkan menggunakan pola dan hubungan untuk menganalisis situasi matematik. Siswa FD cenderung kesulitan dalam menemukan bentuk sederhana yang terdapat di dalam bentuk rumit seperti pada tes GEFT. Hal ini menyebabkan siswa FD kurang mampu menangani masalah yang kompleks. Seperti yang diungkapkan Ngilawajan (2013), siswa dengan FD cenderung sulit untuk memisahkan suatu informasi yang diterima dari hal-hal konteks disekitarnya dan tidak selektif dalam menyerap informasi. Selain itu siswa FD cenderung mengalami kesulitan memecah informasi menjadi bagian-bagian yang terisolasi (Onyekuru, 2015).

Hasil uji statistik menunjukkan gaya kognitif Field Dependent berpengaruh terhadap kemampuan penalaran matematis sebesar $14,6 \%$. Kemudian dilakukan uji lanjut menggunakan Uji Scheffe' diketahui bahwa kemampuan siswa FD dalam melaksanakan perhitungan berdasarkan aturan atau rumus tertentu lebih tinggi dari kemampuan memberikan penjelasan menggunakan model dan kemampuan menggunakan pola dan hubungan untuk menganalisis situasi matematik. Sementara kemampuan menggunakan pola dan hubungan untuk menganalisis situasi matematik lebih tinggi dibandingkan kemampuan memberikan penjelasan menggunakan model. Sehingga dapat disimpulkan bahwa kemampuan melaksanakan perhitungan berdasarkan aturan atau rumus tertentu merupakan kemampuan penalaran matematis yang paling unggul dari siswa FD.

\section{Siswa yang Memiliki Gaya Kognitif Field Independent (FI)}

Siswa yang memiliki gaya kognitif Field Independent memiliki nilai rata - rata sangat baik dalam melaksanakan perhitungan berdasarkan aturan atau rumus tertentu. Hal ini sesuai dengan hasil penelitian Annur, Sujadi, \& Subanti (2016) yaitu siswa dengan FI terlihat lebih lancar, lebih cepat dalam pengerjaan dan memunculkan jawaban yang sudah ia yakini kebenarannya. Dalam menggunakan pola dan hubungan untuk menganalisis situasi matematik, siswa FI memiliki nilai rata-rata baik. Hal ini terlihat pada tes GEFT, 
siswa dengan FI dapat lebih mudah menemukan bentuk sederhana di dalam bentuk rumit dan dapat mengabaikan garis-garis yang tidak diperlukan. Oleh karena itu dalam menyelesaikan masalah siswa FI mahir dalam menggunakan pola dan menganalisis situasi matematik. Sejalan dengan hal tersebut Ngilawajan (2013) juga menyatakan bahwa siswa dengan FI tidak terlalu sulit dalam memisahkan informasi yang esensial dari konteksnya dan lebih selektif dalam menyerap informasi yang diterima.

Hasil uji statistik menunjukkan gaya kognitif Field Independent berpengaruh terhadap kemampuan penalaran matematis sebesar 31,3\%. Setelah dilakukan Uji Scheffe' diketahui bahwa kemampuan siswa FI dalam menggunakan pola dan hubungan untuk menganalisis situasi matematik dan melaksanakan perhitungan berdasarkan aturan atau rumus tertentu lebih tinggi dibandingkan dengan memberikan penjelasan menggunakan model. Sementara kemampuan melaksanakan perhitungan berdasarkan aturan atau rumus tertentu lebih tinggi dibandingkan kemampuan menggunakan pola dan hubungan untuk menganalisis situasi matematik. Sehingga dapat disimpulkan bahwa kemampuan melaksanakan perhitungan berdasarkan aturan atau rumus tertentu merupakan kemampuan penalaran matematis yang paling unggul dari siswa FI.

\section{KESIMPULAN}

Dari hasil penelitian ini secara umum dapat disimpulkan kelompok siswa yang memiliki gaya kognitif Field Independent memiliki nilai rata-rata tes kemampuan penalaran matematis lebih tinggi daripada kelompok siswa yang memiliki gaya kognitif Field Dependent. Hasil analisis untuk tiap indikator soal menunjukkan kedua kelompok siswa masih kurang dalam menguasai indikator 1 yaitu memberi penjelasan dengan menggunakan model. Untuk indikator 2 yaitu menggunakan pola dan hubungan untuk menganalisis situasi matematik, kemampuan kelompok siswa dengan FI lebih baik daripada kelompok siswa dengan FD. Sementara untuk indikator 3 yaitu melaksanakan perhitungan berdasarkan aturan atau rumus tertentu, kedua kelompok siswa dapat menguasainya dengan baik ditunjukkan dengan rata-rata nilai baik. Dapat disimpulkan bahwa siswa yang memiliki gaya kognitif Field Independent memiliki kemampuan penalaran matematis lebih baik dari siswa yang memiliki gaya kognitif Field Dependent, dilihat dari penguasaan ketiga indikator kemampuan penalaran matematis untuk materi sistem persamaan linier tiga variabel dalam penelitian ini.

Hasil uji statistik menunjukkan pengaruh gaya kognitif Field Independent terhadap kemampuan penalaran matematis sebesar 16,7\% lebih tinggi daripada gaya kognitif Field 
Dependent. Kedua kelompok siswa sama-sama unggul dalam kemampuan melaksanakan perhitungan berdasarkan aturan atau rumus tertentu. Sementara kemampuan memberi penjelasan dengan menggunakan model merupakan kemampuan dengan penguasaan terendah dari kedua kelompok.

Dari hasil penelitian ini terlihat 30\% siswa yang menjadi sampel dalam penelitian ini masih memiliki nilai kurang pada tes kemampuan penalaran matematis. Hal ini menunjukkan bahwa kemampuan menggunakan pola, menganalisis situasi matematis dan memberi penjelasan menggunakan model dalam penyelesaian masalah matematika merupakan hal yang masih sulit dikuasai oleh siswa. Untuk itu kegiatan pembelajaran matematika harus dirancang sedemikian rupa agar dapat menumbuhkan dan mengembangkan kemampuan penalaran matematis siswa.

Penelitian ini hanya menguji siswa kelas $\mathrm{X}$ kelompok peminatan Ilmu Pengetahuan Sosial (IPS), sehingga hasil penelitian ini mungkin belum lengkap untuk siswa dalam kelompok peminatan Matematika dan Ilmu Pengetahuan Alam (MIPA) ataupun siswa tingkat XI dan XII. Pengetahuan mengenai sebaran gaya kognitif Field Independent dan Field Dependent siswa dapat menjadi dasar atau landasan untuk guru merancang pembelajaran yang sesuai dan tepat. Selain itu dengan mengetahui gaya kognitif siswa, baik siswa maupun orangtuanya dapat mengoptimalkan kegiatan belajar di rumah sesuai dengan karakteristiknya. Dukungan guru di kelas terhadap perbedaan gaya kognitif siswa dapat ditunjukkan dalam bentuk perhatian dan bantuan terhadap siswa yang memiliki gaya kognitif Field Dependent serta memberikan tantangan dan soal analisis kepada siswa yang memiliki gaya kognitif Field Independent.

\section{REFERENSI}

Annur, M. F., Sujadi, I., \& Subanti, S. (2016). Aktivitas Metakognisi Siswa Kelas X SMAN 1 Tembilahan dalam Pemecahan Masalah Matematika ditinjau dari Gaya Kognitif, 4(7), 720-730.

Basir, M. A. (2015). Masalah Matematis Ditinjau Dari Gaya Kognitif. Jurnal Pendidikan Matematika FKIP Unissula, 3, 106-114. Retrieved from http://research.unissula.ac.id/file/publikasi/211312009/905jurnal_edisi_3_no_1_th_ 2015.pdf

Ferrini-Mundy, J. (2001). Introduction: Perspectives on Principles and Standards for School Mathematics. School Science and Mathematics, 101(6), 277-279. https://doi.org/10.1111/j.1949-8594.2001.tb17957.x

Fisher, D. (2017). Peningkatan Kemampuan Penalaran Matematis Mahasiswa Calon Guru Matematika Melalui Blended- Learning Dengan Strategi Probing-Prompting. Pasundan Journal of Research in Mathematics Learning and Education, 2(2), 7886.

Hidayat, B. R., Sugiarto, B., \& Pramesti, G. (2013). Analisis Kesalahan Siswa Dalam 
Menyelesaikan Soal Pada Materi Ruang Dimensi Tiga Ditinjau Dari Gaya Kognitif Siswa ( Penelitian dilakukan di SMA Negeri 7 Surakarta Kelas X Tahun Ajaran 2011 / 2012 ). Jurnal Pendidikan Matematika Solusi, 1(1), 39-46.

Hill, W. F. (2010). Theories Of Learning , Teori - Teori Pembelajaran. (A. Khozim. M, Prihatmoko, Ed.) (Cetakan IV). Bandung: Nusa Media.

Ibda, F. (2015). Perkembangan Kognitif: Teori Jean Piaget. Jurnal Intelektualita, 3(1), 27 38.

Kemendikbud. (2016). Permendikbud Nomor 21 Tahun 2016 Tentang Standar Isi Pendidikan Dasar Dan Menengah (Lampiran), 1-234. https://doi.org/10.1017/CBO9781107415324.004

Khoiriyah, N. (2013). Analisis Tingkat Berpikir Siswa Berdasarkan Teori Van Hiele Pada Materi Dimensi Tiga Ditinjau dari Gaya Kognitif Field Dependent dan Field Independent. Universitas Sebelas Maret Surakarta.

Ngilawajan, D. A. (2013). Proses Berpikir Siswa Sma Dalam Field Independent Dan Field Dependent. Pedagogia, 2(1), 71-83. https://doi.org/10.21070/pedagogia.v2i1.48

Nufus, H., \& Ariawan, R. (2017). Keterkaitan Hubungan antara Kemampuan Komunikasi dan Penalaran Matematis Siswa. Pasundan Journal of Research in Mathematics Learning and Education, 2, 29-42.

Onyekuru, B. U. (2015). Field Dependence-Field Independence Cognitive Style , Gender, Career Choice and Academic Achievement of Secondary School Students in Emohua Local Government Area of Rivers State. Journal of Education and Practice, 6(10), 76-86.

Rozestraten, R. J. A., \& Pottier, A. (1988). Educational levels and field-dependent/fieldindependent perceptual style. Bulletin of the Psychonomic Society, 26(3), 212-213. https://doi.org/10.3758/BF03337290

Sumarmo, Y. P. dan U. (2007). Mengembangkan Kemampuan Penalaran dan Koneksi Matematik Siswa SMA Melalui Pembelajaran Berbasis Masalah. Educationist, I(2), $116-123$.

Susongko, P. (2010). Perbandingan Keefektifan Bentuk Tes Uraian dan Teslet dengan Penerapan Grade Response Model (GRM). Jurnal Penelitian Dan Evaluasi Pendidikan, (3), 269-288. https://doi.org/10.21831/PEP.V14I2.1082

Witkin, H. A., Moore, C. A., Goodenough, D., \& Cox, P. W. (1977). Field-Dependent and Field-Independent Cognitive Styles and Their Educational Implications. Review of Educational Research, 47(1), 1-64. https://doi.org/10.3102/00346543047001001 